\title{
Starch producing in microalga biomass as a raw material for bioethanol
}

\author{
Fiona Putri ${ }^{1}$, Mawar DS Silalahi ${ }^{1}$, and Astri Rinanti ${ }^{1 *}$ \\ ${ }^{1}$ Universitas Trisakti, Enviomental Engineering Departement, Faculty of Landscape Architecture and Enviromental Technology, Jakarta, \\ Indonesia
}

\begin{abstract}
A preliminary research in the field of environmental biotechnology to the production of biofuel from the tropical microalga consortium consisting of Chlorella vulgaris and Closterium sp have been done. Microalga cultivation in batch culture are controlled at temperature of $25^{\circ} \mathrm{C}, \mathrm{PH} 6$, aeration of $1 \mathrm{ml} / \mathrm{sec}$, and lights of 4000 lux. Nutrient sources utilize artificial Provasoli Heamatococcus Media which consist of micro and macro nutrients. Analysis of bioethanol from microalga start with finding the maximum starch production from wet weight of biomass, dried weight of biomass, and at hydrolysis. Hydrolysis is proceeded by adding HCL 1 Molar as much as 0.04 grams of dried weight of biomass. The analysis of starch is proceeded by nelson samogy method by adding alkali and pre reaction arsenomolibdat. Absorbent is measured through the wave length $540 \mathrm{~nm}$ by spectrofotometre. The average of dried weight biomass is 0,8 grams/liter. Research reveal that the highest starch production is occured in microalga consortium at hydrolysis process and produces starch of $88.31 \%(\mathrm{v} / \mathrm{v})$. The two types of tropical microalgae have a potential as solid compound of bioethanol.
\end{abstract}

\section{Introduction}

The lack of sources of crude oil has increased the price of fuel causing influencing the global economy. In an effort to decrease global warning and the concern towards the decreasing supply of crude oil, scientist, the industry and the government has seek new sources of energy. One of the promising fuel source is the biomass basis fuel alternative [1].

Currently, natural sources as forestry and agriculture, residue, waste and biomass has been an prime contributor for the demand of world energy [1]. Biomass is produced by land plants and algae converted to biofuel and biogas [1]. The prime advantage of biomass energy that is renewable and pollution free [2]. Biofuel and biogas is produced from biomass as an alternative towards fuel-based sources.

Algae is an organism which has a simple structure, sans roots, stems or leaves [3]. Microalgae is a algae that is unicellular microscopic with the ability of photosynthesis and which results as oxygen [3]. The cultivation of microalgae becomes a primary step in the whole production process of microalgae production as raw bioenergy. The cultivation of microalgae is dependent on the environmental condition such as climate, water sources, $\mathrm{CO}_{2}$, and other methods of cultivation [4]. Those factors that have direct impact to the growth of microalgae. The production process of microalgae do not require herbicides and pesticides which are toxic whereby algae becomes the potential alternative for fossil fuel that is environmental friendly [4].

Bioethanol represents one of the fuel that is in the process of renewal. The contents of oil extraction microalgae is able to produce bioethanol at the production level of $38 \%$ [5]. In the future. The priority of ethanol production will be dependable in the processing of lignoselulose which is considered as one of the promising second generation of biofuel [6]. All things considered, at the this point the utilization of cellulose as a raw material of sugar-based ethanol and starch is more dominant in the industrial level and more economically profitable in comparison to lignocellulose due to the technology of waste processing which contain lignocellulose has not been developed commercially [7].

The conventional process for the bioethanol production from starch basis to be fermented to become sugar that can be proceeded into two enzymatic steps: liquefaction using thermal stable alpha amylase and sacrifices with the addition of amiloglukosidase (AMG) [8].

The starch content in microalagae depends on species and the environment [9]. In the growth of microalgae, environment control such as nutrients, light, and temperature will have an impact on microalgae growth and biomass, recent studies have shown that growth involves limiting nutrients such as sulfur, nitrogen and phosphates to increase carbohydrate levels in microalgae by forcing them to change from proteins or peptides to be carbohydrates [10].

\footnotetext{
* Corresponding author: astririnanti@trisakti.ac.id
} 
The hydrolysis process is able to break down cellulose in microalgae with higher efficiency [11]. The high viscosity has resulted with several difficulties in the processing and caused. The high ethanol concentration can be achieved by fermentation contain high sugar that can be fermented. The high viscosity has resulted with several difficulties in the processing and caused undeveloped hydrolysis starch to become fermented sugar [12].

Starch with the chemical formula $\left(\mathrm{C}_{6} \mathrm{H}_{10} \mathrm{O}_{5}\right)$ is polysaccharide carbohydrates units of $t$ is composed of high units of glucose which is compounded into glyosidic bond. Starch composed of amylase (linear glucose) and amilopektik (glucose chain reserve). Starch can be found in various plants as primary carbohydrate reserve which supply various important energy [13]. Carbohydrates at microalgae is locate at the walls of cells and cytoplasm. Around $4-7 \%$ in the form of cellulose and $51-60 \%$ in the form of neutral noncellulose sugars [14].

Bioethanol as biofuels is considered to have better prospects for development in comparison to biodiesels. This is due to bioethanol raw materials originating from biomass microalgae directly extracted from its fat contents [5].

The research is to determine the contents of carbohydrates from the combination of two types of microalgae in one form of consortium. The contents of carbohydrates in the wet weight of microalgae biomass, dried weight of microalgae biomass and the result of hydrolysis from dried weight of microalgae biomass.

\section{Research and methodology}

Research begins with the formation of artificial PHM (Provasoli Heamatocuccus Media) media growth for microalgae Chorella vulgaris, Closterium sp. The next step of the research is exhibited in Fig 1.

After the creation of media growth, microalgae is cultivated inbatch Erlenmeyer $1 \mathrm{~L}$. Addition of molase needed to bring nutrition to microalgae for better growth. The microalgae is cultivated by the ideal room temperature of $25^{\circ} \mathrm{C}$ with aeration $100 \mathrm{ml} / \mathrm{sec}$ and controlled lighting at 4000 lux

Wet weight of biomass and dried weight of biomass measured by gravimetric method. Weighted wet microalgae is determined after microalgae growth reaching the density of $10^{6} \mathrm{mg} / \mathrm{l}$.

Microalgae dystryfugation with speed capacity of $150 \mathrm{rpm}$. Deposits is weighted as wet weight of microalgae biomass. Dried weight of microalgae biomass is resulted from after decentration microalgae and deposited and dried by use of oven.

Hydrolysis is proceeded by dripping $\mathrm{HCl}$ with 1 molar concentration by the microalgae sample that have been dried. The starch contents as follows: samples that have been de hydrolysis is piped as much as $1 \mathrm{ml}$ and added by $1 \mathrm{~mL}$ reagen nelson. Sample are heated in water for 20 minutes. Cooled down to room temperature and added with $1 \mathrm{~mL}$ fosfomolibdat and added with $7 \mathrm{~mL}$ aquadest. Absorbent is measured through the wave length $540 \mathrm{~nm}$ by spectrofotometre

The calculation of dried weight and starch percentage are as follows:

$$
\% \text { Dried Weight of Biomass }=\left(\frac{A}{B+A}\right) \times 100 \%
$$

A: Dried Weight of Biomass

B: Weight of the Grate

$$
\% \operatorname{Starch}=\left(\frac{A}{B+A}\right) \times 100 \%
$$

A: Weight of Starch

B: Weight of Biomass

\begin{tabular}{|c|}
\hline Artificial Media \\
\hline Provasoli Heamatococcus Media/ PHM \\
\hline A. Preparation \\
\hline $\begin{array}{c}\text { Microalgae Cultivation (Chlorella vulgaris, } \\
\text { Closterium sp., dan Chlorella vulgaris + Closterrium } \\
\text { sp.) batch culture are controlled at temperature of } \\
25^{\circ} \mathrm{C}, \mathrm{PH} \text {, aaeration of } 1 \mathrm{ml} / \mathrm{sec} \text {, and lights of } 4000 \\
\text { lux }\end{array}$ \\
\hline 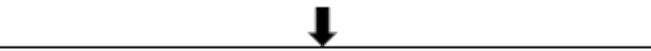 \\
\hline Wet Weight of Biomass \\
\hline $\begin{array}{l}\text { With centrifuge process after microalgae growth } \\
\text { reaching the density of } 10^{\circ} \mathrm{mg} / 1 \text {. }\end{array}$ \\
\hline Dried Weight of Biomass \\
\hline Dried with oven with temperature $160^{\circ} \mathrm{C}$ \\
\hline B. Hydrolysis \\
\hline Dripping $\mathrm{HCl}$ with concentration $1 \mathrm{M}$ \\
\hline $\begin{array}{c}\text { Concentration } 0.04 \text { gram of dried biomass in } 1 \mathrm{ml} \\
\mathrm{HCl} \text { with temperature } 160^{\circ} \mathrm{C}\end{array}$ \\
\hline Starch Analysis \\
\hline $\begin{array}{l}1 \mathrm{~mL} \text { sample }+1 \mathrm{~mL} \text { reagent Nelson, heated in } \\
\text { water for } 20 \text { minutes. Cooled down to room } \\
\text { temperature and added with } 1 \mathrm{~mL} \text { fosfomolibdat }+ \\
7 \mathrm{~mL} \text { aquadest. Absorbent is measured through the } \\
\text { wave length } 540 \mathrm{~nm} \text { by spectrophotometer }\end{array}$ \\
\hline
\end{tabular}

The stages of this research can be seen in Fig 1.

Fig. 1. Methodology.

\section{Results and discussion}

Table 1 shows that both microalagae are combined in the consortium, then the potential result of both starch will be greater reaching $88.31 \%$. The percentage largest of 
starch is the result of hydrolysis from mixing the Closterium sp consortium and Chlorella vulgaris. This is due to the strong acid that has broken the cell walls of microalgae containing cellulose causing an increase in the percentage of starch.

The amount of starch that is converted to glucose is due to acid concentration, conversion time, temperature and pressure during reaction. Acid hydrolysis produces a cheaper process option but the product result is not as well as enzymatic hydrolysis which costs much more. However, in acid hydrolysis, the hydrolysis process can occur in just a few minutes while enzyme hydrolysis may take several days. The acid added in the hydrolysis process acts as a catalyst to speed the polysaccharide chain termination reaction towards glucose because the natural hydrolysis process uses water for a very long time. The addition of hydrochloric acid $(\mathrm{HCl})$ in the process of acid hydrolysis will produce a starch with a relaxed structure so that during the drying process the water is more volatile. This can indirectly increase the resulting ethanol conversion [15].

The percentage of starch content in wet biomass, dry biomass, and hydrolyzed biomass can be seen in Fig 2, Fig 3, and Fig 4.

Table 1. Starch Precentage.

\begin{tabular}{|l|c|c|c|}
\hline Mikroalga & $\begin{array}{c}\text { Wet } \\
\text { Biomass }\end{array}$ & $\begin{array}{c}\text { Dried } \\
\text { Biomass }\end{array}$ & Hydrolysis \\
\hline Closterium sp. & $3.42 \%$ & $38.50 \%$ & $78.98 \%$ \\
\hline Chlorella vulgaris & $3.54 \%$ & $36.60 \%$ & $57.16 \%$ \\
\hline $\begin{array}{l}\text { Closterium sp. }+ \\
\text { Chlorella vulgaris }\end{array}$ & $3.88 \%$ & $42 \%$ & $\mathbf{8 8 . 3 1 \%}$ \\
\hline
\end{tabular}

In Fig 1 it appears that microalgae in a single culture Closterium sp. and Chlorella vulgaris before being hydrolyzed, both wet and dried biomass each produce metabolites in the form of starch although the percentage is small. After hydrolysis, the two single cultures of Closterium sp. and Chlorella vulgaris each experience an increase in starch content.

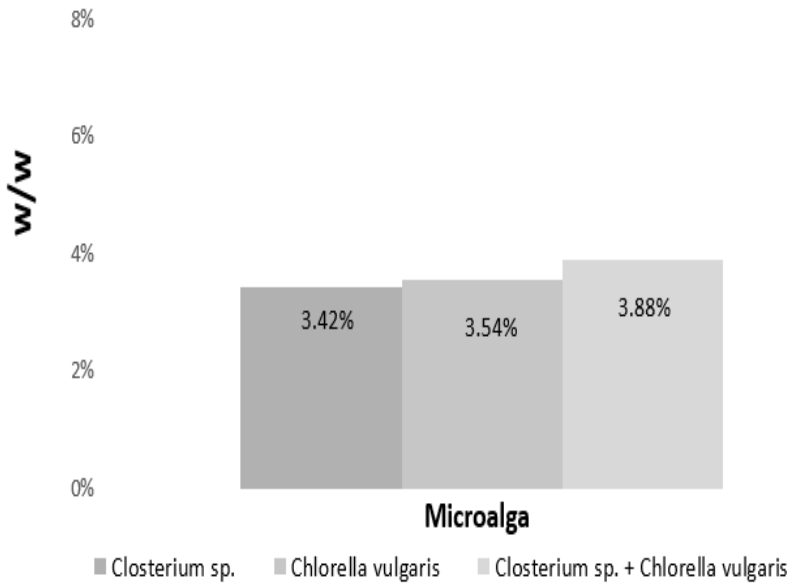

Fig. 2. Wet weight of microalagae biomass precentage.

Wet weight of microalgae biomass is dried after centrifugation process for 15 minutes and drying with temperature of $160 \mathrm{C}$ with oven. Research shows that starch will increase from wet weight of biomass to dried weight of biomass seen in Fig 2. This is due to the centrifugation and drying process.

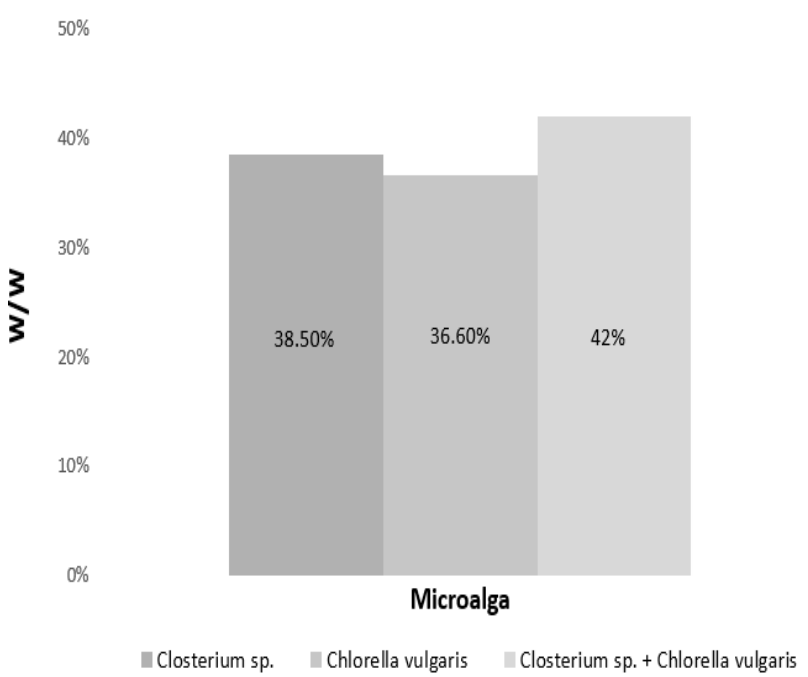

Fig. 3. Dried weight of microalagae biomass precentage.

After the addition of a strong acid $\mathrm{HCl}$ of $1 \mathrm{M}$ with a concentration of 0.04 grams / L, reveal that the percentage of carbohydrate has increased. This method is done to break the cell wall, so that carbohydrates in the cell wall decays and increase the percentage of carbohydrates by using hydrolysis process. The results are shown in Fig 3. The hydrolysis process is required to maximize the carbohydrates needed for the manufacture of bioethanol.

The basic principle of hydrolysis is to cut $\alpha-1,4-$ glucoside bonds and $\alpha$-1,6-glucoside bonds from ectoprotics to produce smaller starch (glucose). In the hydrolysis process, things to note such as the type and amount of benzyme or acid used, the size of the hydrolyzed part, the operating conditions such as temperature, $\mathrm{pH}$, hydrolysis time, stirring and starter volume ratio to hydrolysis until the liquid to the raw material (volume substrate) for hydrolyzed. Incorrect operating conditions may provide hydrolysis result that is not optimal [15].

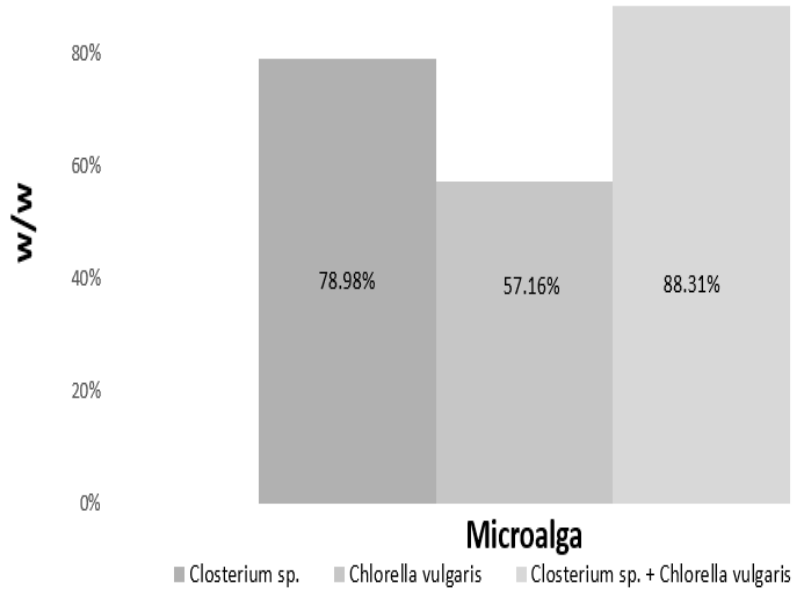

Fig. 4. Hydrolysis result from dried weight of microalgae biomass percentage. 
The hydrolysis result will then be fermented using Saccharomyces cerevicae. After the fermentation process, an analysis will be done by using GC-MS (Gas chromatography-mass spectrometry) to see the alcohol content.

\section{Conclusions}

From the results of this study can be concluded that the hydrolysis process will produce more starch than if without a process of hydrolysis. The highest starch content is produced by mixing Closterium sp. and Chlorella vulgaris by $88.31 \%$ by hydrolysis process. In addition, this study also showed that without special treatment, microalgae in nature already contains starch that has the potential to become bioethanol. Thus in the absence of special treatment such as hydrolysis, tropical microalgae Chlorella vulgaris and Closterium sp. has great potential as a bioethanol feedstock.

\section{References}

1. Sims R., Taylor M. From 1st to 2 st Generation Biofuel Technologies, International Energy Agenvy (IEA Bioenergy), pp 16-38. (2008)

2. Wu C., Z. X., Zhou F., Cao H. "The Analysis of Biomass Energy UseTechnology development" Chinese Renewable Energy 29: 35-41. (2007)

3. Andersen R.A, Richmond A. Emeritus: Handbook of Microalgal Culture. Appl. Microbiol. Biotechnol 2nd Edition. Wiley Blackwell: West Sussex 3. (2013)

4. L. Brennan, P. Owende. Biofuels from microalgae-A review of technologies for production, processing, and extractions of biofuels and co-products. (2010)

5. R. Harun, M.K Danquah, G. M Forde. Micro alga biomass as a fermentation feedstock for bioethanol production. Journal of Chemical Technology \& Biotechnology. 85 (2): 199-203. (2009)

6. J. P. Lange. Biofuels, Bioprod. Biorefin. 39-4. (2007)

7. M. Balat, H. Balat. Appl. Energy 86. 2273-228 (2009)

8. Duvernay WH, Chinn MS, Yencho GC. Hydrolysis and fermentation of sweet potatoes for production of fermentable sugars and ethanol. Ind Crop Prod 42:527-537. (2013)

9. Basmal, J. Peluang dan tantangan rekreasi mikroalga sebagai biofuel. Squalen Buletin Pascapanen Bioteknologi Kelautan dan Perikanan 3 (1): 34-39 (2008)

10. T. Mata. Microalgae for Biodiesel Production and Other Applications: A review. Jurnal renewable and sustainable energy reviews. 14 (1): 217-232. (2010)

11. Rabelo SC., Filho RM, dan Costa, AC. Lime pretreatment of sugarcane bagasse for ethanol production. Appl Biochem Biotechnol; 153:139-50. (2009)
12. Shanavas S, Padmaja G, Moorthy SN, Sajeev MS, Sheriff JT. Process optimization for bioethanol production from cassava starch using novel ecofriendly enzymes. Biomass Bioenergy 35:901-909. (2011)

13. W.M, Marrs. The properties and uses of natural and modified starches. (1975)

14. J. VanderGheynst. The future of microalgae in cleantechnologies. (2008)

15. J. BeMiller, R. Whistler. Chemistry and Technology $3^{\text {rd }}$ ed. P. 310- 315. (2009) 